\title{
Typha domingensis leaf powder for decontamination of aluminium, iron, zinc and lead: Biosorption kinetics and equilibrium modeling
}

\author{
${ }^{1}$ N. T. Abdel-Ghani; ${ }^{2}$ A. K. Hegazy; ${ }^{3 *}$ G. A. El-Chaghaby \\ ${ }^{1}$ Chemistry Department, Faculty of Science, Cairo University, Giza, Egypt \\ ${ }^{2}$ Botany Department, Faculty of Science, Cairo University, Giza, Egypt \\ ${ }^{3}$ Agriculture Research Center, Giza, Egypt \\ Received 22 December 2008; revised 14 January 2009; accepted 19 February 2009; available online 1 March 2009
}

\begin{abstract}
The present study explores the effectiveness of Typha domingensis leaf powder for simultaneous removal of aluminium, iron, zinc and lead ions from aqueous solution. Batch experiments were carried out in laboratory at room temperature and at initial ions concentrations simulating the concentrations of these cations in real wastewater samples. The sorption process was examined applying the first and second order kinetic mechanisms. The results were best described by the second order rate kinetics. The applicability of the three equilibrium isotherm models was investigated. The obtained data follow the three investigated isothermal models in the following order: Langmuir > Freundlich $>$ Temkin, for all the studied metal ions. The infrared spectra of native and exhausted Typha leaf powder confirmed ions-biomass interactions responsible for sorption. The results showed that Typha domingensis leaf powder can easily be envisaged as a new low cost natural biosorbent for metal clean up operations in aquatic systems.
\end{abstract}

Keywords: Batch experiments, contact time, infrared spectra, isotherm models

\section{INTRODUCTION}

Wastewater discharged by industrial activities has been a matter of worldwide concern over the last few decades posing serious environmental concerns. Metal ions represent a major class of pollutants introduced into aquatic system significantly as a result of various industrial and agricultural operations (Chandra et al., 2003). Different countries are devoting concentrated efforts for the treatment and removal of heavy metals in order to combat this problem. The commonly used procedures for removing metal ions from aquatic ecosystems include chemical precipitation, reverse osmosis and solvent extraction (Bayat, 2002; Gupta and Torres, 1998). However, these techniques have certain disadvantages such as incomplete metal removal, high reagent and energy requirements, generation of toxic sludge or other waste products that require disposal (Chandra et al., 2003). The search for alternate and innovative treatment techniques has focused attention on the use of biological materials for heavy metal removal and recovery technologies (biosorption) and has gained important credibility during recent years because of the good performance and low cost of this complexing materials (Chandra et al., 2003). Different types of

*Corresponding Author Email: ghadiraly@yahoo.com Tel./Fax: +0101 235184 biosorbents were investigated for metals removal from wastewater (Abdel-Ghani and El-Chaghaby, 2008; AbdelGhani et al., 2008; Horsfall and Abia, 2003; Singh et al., 2005; Zafar et al., 2007). Among many biosorbents naturally available plant biomass can be used as an inexpensive method for metal ions removal from synthetic solutions and industrial effluents (Manal, 2007). In the present investigation, the potential of Typha domingensis leaf powder has been assessed for the removal of metal ions such as aluminium, iron, zinc and lead. Typha domingensis was selected as it is a widespread and dominant plant in many aquatic systems. The species are also grown in industrial wastewater lakes which indicate that the plant is resistant to pollution. The effects of various parameters affecting the removal of metal ions by biosorption onto Typha domingensis leaf powder were studied and the results are discussed.

The present study was performed during 2008 at the Agriculture Research Center in Egypt.

\section{MATERIALS AND METHODS}

Biosorbent preparation and characterization

Fresh biomass of Typha domingensis were collected from Sadat city, Menoufia Governorate, Egypt. Before use, the biomass was washed with deionized water to remove dirt. The biomass was then air dried for 10 days 
followed by drying in an oven at $70{ }^{\circ} \mathrm{C}$ for $24 \mathrm{~h}$. Subsequently, it was ground. Elemental analysis of the prepared biosorbent was estimated. The amounts of hemicellulose, lignin and cellulose in the biosorbent material were determined. Fourier transformation infrared (FTIR) of the biosorbent was also obtained.

Determination of $\mathrm{Al}, \mathrm{Fe}, \mathrm{Zn}$ and $\mathrm{Pb}$

Al (III), Fe(III), $\mathrm{Zn}(\mathrm{II})$ and $\mathrm{Pb}(\mathrm{II})$ were simultaneously determined using a Perkin Elmer inductively coupled plasma optical emission spectrometer (ICP-OES), model Optima 2000DV.

\section{Batch experiments}

Batch sorption experiments were performed at a constant temperature of $25^{\circ} \mathrm{C}$ in a Shaking water bath at $100 \mathrm{rpm}$ using125 mL capped conical flasks. Al (III), Fe (III), Zn (II) and $\mathrm{Pb}$ (II) working solutions were prepared in deionized water using aluminium, iron, zinc and lead 1000 ppm stock solutions (Merck). In all sets of experiments, $0.5 \mathrm{~g}$ of Typha leaves powder was thoroughly mixed into $50 \mathrm{~mL}$ mixed $\mathrm{Al}, \mathrm{Fe}, \mathrm{Zn}$ and $\mathrm{Pb}$ ions solutions. In order to investigate the effect of contact time on metals removal by adsorption onto Typha biomass a known weight $(0.5 \mathrm{~g})$ of biomass was added to a mixed metal ion solution containing $7 \mathrm{ppm}(\mathrm{Al}), 10$ ppm (Fe), 4 ppm (Zn) and 1 ppm (Pb) simulating the concentrations of these cations in real wastewater samples collected from industrial wastewater lake at Sadat city, Egypt. The $\mathrm{pH}$ was measured and found to be 2.5. The solutions were shaken well in a shaking water bath at 100 rpm at room temperature for 30, 60, 90, 120,150 and $240 \mathrm{~min}$. The slurry, after equilibration, was filtered through Whatman 41 filter paper. The clear filtrate was analyzed for metal concentration using a Perkin Elmer inductively coupled plasma-optical emission spectrometer ICP-OES Optima 2000 DV. The amount of metal taken up by plant biomass was calculated as the difference between the initial and final concentrations of metal after adsorption in the aqueous solution. The removal efficiency was calculated according to the following equation:

Removal efficiency $(\mathrm{R})=\left(\mathrm{C}_{0}-\mathrm{C}_{\mathrm{f}}\right) \times 100 / \mathrm{C}_{0}$

Where, $\mathrm{C}_{0}$ and $\mathrm{C}_{\mathrm{f}}$ are the initial and final ions concentrations, respectively. In order to investigate the mechanism of biosorption, the pseudo first order and pseudo second order equations were used to test experimental data. The first order rate expression of
(Lagergren, 1898) based on solid capacity is generally expressed as follows:

$\mathrm{d} Q / \mathrm{d} t=k_{1, \text { ads }}\left(Q_{e q}-Q\right)$

The pseudo second-order equation is also based on the sorption capacity of the solid phase (Ho and McKay, 1999), contrary to the other mechanism being the rate controlling step. If the rate of sorption is a second order mechanism, the pseudo second order chemisorption kinetic rate equation is expressed as:

$\mathrm{d} Q / \mathrm{d} t=k_{2, \text { ads }}\left(Q_{e q}-Q\right)^{2}$

The experimental amount of metal ion biosorption $\left(Q_{e q}\right)$ per gram of biomass was calculated by the following equation:

$Q_{e q}=\mathrm{V}\left(\mathrm{C}_{0}-\mathrm{C}_{\mathrm{f}}\right) / \mathrm{m}_{\mathrm{s}}$

Where, $\mathrm{C}_{0}(\mathrm{mg} / \mathrm{L})$ is the initial concentration, $\mathrm{C}_{\mathrm{f}}$ ( $\mathrm{mg} / \mathrm{L}$ ) is the final or equilibrium concentration, $\mathrm{V}(\mathrm{L})$ is the volume of solution and $\mathrm{m}_{\mathrm{s}}(\mathrm{g})$ is the biosorbent mass (drybase). Equilibrium data, which are commonly known as adsorption isotherms, are basic requirements for the design of adsorption systems. This set of experiments was performed at different initial ions concentrations. Classical adsorption models (Langmuir, Freundlich and Temkin) were used to describe the equilibrium between adsorbed metal ions on the Typha biomass $\left(\mathrm{Q}_{\mathrm{eq}}\right)$ and metal ions in solution $\left(\mathrm{C}_{\mathrm{eq}}\right)$ at a constant temperature.

\section{RESULTS AND DISCUSSION}

\section{Biosorbent characterization}

Biosorbent composition

Typha domingensis leaf powder subjected to elemental analysis showed composition of carbon, hydrogen, nitrogen and sulphur as 43.35, 10.06, 2.49 and $1.21 \%$, respectively. The leaf powder was also found to contain 31.17, 34.09 and $4.16 \%$ hemicellulose, cellulose and lignin, respectively.

\section{Infrared spectra of the biosorbent}

The FTIR spectra of fresh-dried (A) metal-loaded (B) Typha biomass are shown in Fig. 1. The spectra display a number of absorption peaks, indicating the complex nature of the examined biomass. Inspection of the spectra reveals the presence of a broad peak at wave number $3400.85 / \mathrm{cm}$ representing surface bonded $\mathrm{O}-\mathrm{H}$ groups or stretching $\mathrm{N}-\mathrm{H}$ groups which was shifted to $3419.17 / \mathrm{cm}$ after adsorption ; The strong absorption 
peak at 2921.63/cm can be assigned to -CH stretching, and those at $1735.62 / \mathrm{cm}$ and $1641.13 / \mathrm{cm}$ assigned to $\mathrm{C}=\mathrm{O}$ stretching and $\mathrm{CO}$ chelate stretching of carboxyl groups, respectively. These peaks also were shifted to $2919.7 / \mathrm{cm}, 1736.58 / \mathrm{cm}$ and $1648.84 / \mathrm{cm}$. The absorption peaks at $1424.1 / \mathrm{cm}$ and $1246.75 / \mathrm{cm}$ can be attributed to the presence of $\left(\mathrm{CH}_{2}\right.$ and $\left.\mathrm{CH}_{3}\right)$ and $-\mathrm{C}-\mathrm{O}$ stretching, respectively. After adsorption these peaks were shifted to 1380.78 and $1247.72 / \mathrm{cm}$. Another peak observed at the biomass surface before adsorption appeared at $1059.69 / \mathrm{cm}$ and was shifted to $1057.76 / \mathrm{cm}$ after adsorption. The peak observed at $603.61 / \mathrm{cm}$ that was shifted to $612.288 / \mathrm{cm}$ after adsorption could be assigned to out of plane $\mathrm{O}-\mathrm{H}$. The shifts in the absorption peaks generally observed indicate the existence of a metal binding process taking place on the surface of Typha biomass (AbdelGhani and El-Chaghaby, 2007; Abdel-Ghani et al., 2007; Horsfall et al., 2006; Ilharco et al., 1997).

\section{Effect of contact time and biosorption kinetics}

The contact time and kinetic parameters are necessary to determine the best operational conditions in a continuous process of ions removal. Many previous authors have investigated the effect of contact time on biosorption process, as well as the biosorption kinetics (Al-Anber and Matouq, 2008; El-Ashtoukhy et al., 2008; Pandey et al., 2008; Selatnia et al., 2004). As shown in Fig. 2, the removal of $\mathrm{Al}$ (III), Fe (III), Zn (II) and $\mathrm{Pb}$ (II) by adsorption onto Typha biomass increases with contact time and attains saturation in about $120 \mathrm{~min}$. Basically, the removal rate of sorbate is rapid, but it

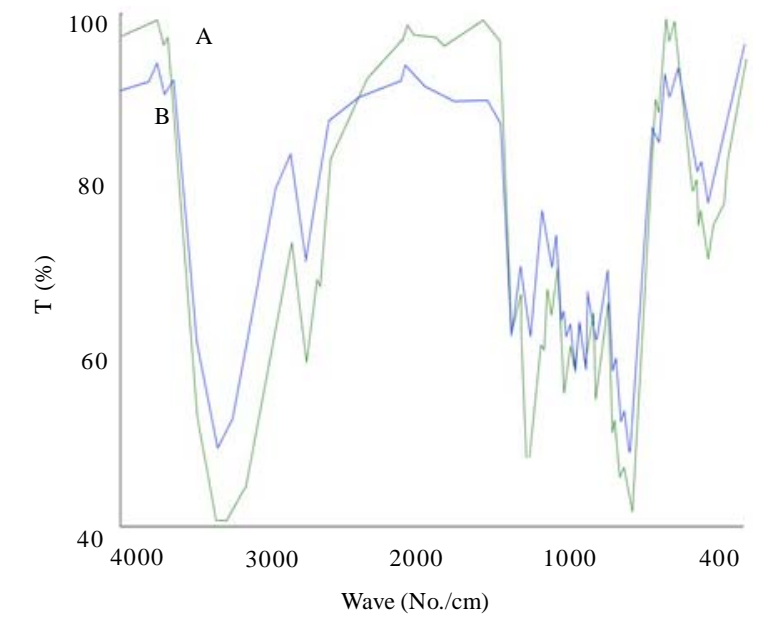

Fig. 1: FTIR spectra of fresh-dried (A) metal-loaded (B) Typha biomass gradually decreases with time until it reaches equilibrium. The rate of percent metal removal is higher in the beginning due to a larger surface area of the adsorbent being available for the adsorption of the metals (ElAshtoukhy et al., 2008). It is also relevant to point out that, since active sorption sites in a system have a fixed number and each active site can adsorb only one ion in a monolayer (Langmuir, 1918), the metal uptake by the sorbent surface will be rapid initially, slowing down as the competition for decreasing availability of active sites intensifies by the metal ions remaining in solution. The rate of metal removal is of greatest significance for developing a natural adsorbent-based water treatment technology. In order to investigate the mechanism of biosorption, kinetic models were used to test experimental data. The kinetic models included the pseudo first order and pseudo second order equations.

After integration and applying boundary conditions, $\mathrm{t}=0$ to $\mathrm{t}=\mathrm{t}$ and $\mathrm{Q}=0$ to $\mathrm{Q}=\mathrm{Q}_{\mathrm{eq}}$; the integrated form of Eq. 2 becomes:

$\ln \left(Q_{e q}-Q\right)=\ln Q_{e q}-k_{1, \text { ads }} t$

A straight line of $\ln \left(Q_{e q}-Q\right)$ versus $t$ suggests the applicability of the pseudo first-order kinetic model (Lagergren, 1898; McKay et al., 1999; Ho and McKay, 1999). The rate constant $k_{1, \text { ads }}$ and the equilibrium amount of metal ion, $\mathrm{Q}_{\mathrm{eq}}$, of Lagergren pseudo first order model can be, respectively, obtained from the slope and intercept of plot . In order to fit Eq. 5 to experimental data, the equilibrium sorption capacity, $\mathrm{Q}_{\mathrm{eq}}$, must be known. In many cases, $\mathrm{Q}_{\mathrm{eq}}$ is unknown and as adsorption tends to become unmeasurably slow, the sorbed amount is still significantly smaller than the equilibrium amount. For this reason, it is necessary to obtain the real equilibrium sorption capacity, $\mathrm{Q}_{\mathrm{eq}}$, by extrapolating the experimental data to $t=1$ or using a trial and error method. Furthermore, in most cases, the first order equation of Lagergren does not fit well for the whole range of contact time and is generally applicable over the initial 20-30 min of the sorption process.

For the boundary conditions, $\mathrm{t}=0$ to $\mathrm{t}=\mathrm{t}$ and $\mathrm{Q}=0$ to $\mathrm{Q}=\mathrm{Q}_{\mathrm{eq}}$, the integrated form of Eq. 3 becomes Eq. 6:

$1 / Q_{e q}-Q=1 / Q_{e q}+k_{2, \text { ads }} t$

Eq. 6 can be rearranged to a linear form: 


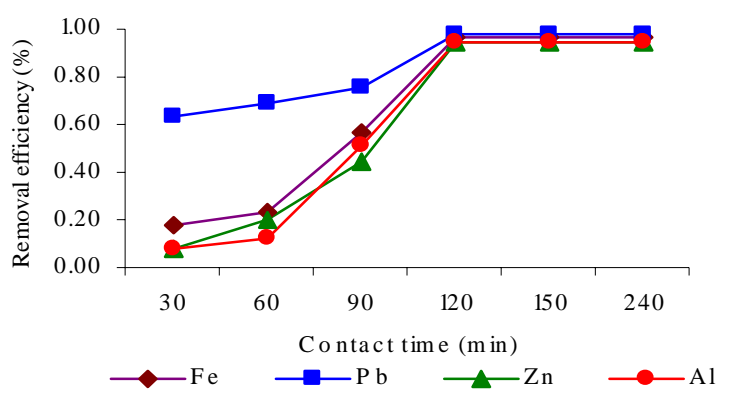

Fig. 2: Effect of contact time on the removal of Al (III), Fe (III), Zn (II) and $\mathrm{Pb}$ (II) by adsorption onto Typha biomass; $\mathrm{pH}$ 2.5; biomass weight: $0.5 \mathrm{~g} / 50 \mathrm{~mL}$; shaking speed: $100 \mathrm{rpm}$; temp.: $250{ }^{\circ} \mathrm{C}$

$$
(\mathrm{t} / \mathrm{Q})=1 / k_{2, \text { ads }} Q_{\text {eq }}^{2}+\left(1 / Q_{e q}\right) t
$$

If second-order kinetics are applicable, the plot of $t / Q$ against $t$ of Eq. 6 should give a linear relationship, from which $\mathrm{Q}_{\mathrm{eq}}$ and $\mathrm{k}_{2, \mathrm{ads}}$ can be determined from the slope and intercept of the plot, respectively and there is no need to know any parameter before hand (Ho and McKay, 1999). The pseudo first-order and pseudo second-order kinetic models were applied to the experimental data. The firstorder and the second-order sorption rate constants for $\mathrm{Al}^{3+}, \mathrm{Fe}^{3+}, \mathrm{Zn}^{2+}$ and $\mathrm{Pb}^{2+}$ as well as the correlation coefficients obtained for each model are presented in Table 1. It can be concluded that the obtained correlation coefficients for the second-order kinetic model were greater than those obtained for the first -order kinetic model. The theoretical $\mathrm{Q}_{\mathrm{eq}}$ values were close to the experimental $\mathrm{Q}_{\mathrm{eq}}$ values in the case of pseudo second-order kinetics. These suggest that the sorption system is the second-order model, based on the assumption that the rate determining step may be the biosorption which provides the best correlation of the data.

\section{Equilibrium modeling}

The Langmuir equation is valid for monolayer sorption onto a surface with a finite number of identical sites and is given by Eq 8:

$$
\mathrm{C}_{\mathrm{eq}} / \mathrm{Q}_{\mathrm{eq}}=1 / \mathrm{b} \mathrm{Q}_{\max }+\mathrm{C}_{\mathrm{eq}} / \mathrm{Q}_{\max }
$$

Where, $\mathrm{Q}_{\max }(\mathrm{mg} / \mathrm{g})$ is the maximum amount of metal ion per unit weight of Typha leaf powder to form a complete monolayer on the surface bound at high $\mathrm{C}_{\mathrm{eq}}$ and $\mathrm{b}(\mathrm{L} / \mathrm{mg})$ is a constant related to the affinity of the biomass surface binding sites when the surface is fully covered with metal ions and assists in the comparison of adsorption performance, particularly in cases where the sorbent did not reach its full saturation. The $\mathrm{Q}_{\max }$ represents a practical limiting adsorption capacity in experiments. The $\mathrm{Q}_{\max }$ and $\mathrm{b}$ can be determined from the linear plot of $\mathrm{C}_{\mathrm{eq}} / \mathrm{Q}_{\mathrm{eq}}$ versus $\mathrm{C}_{\text {eq }}$ (Donmez et al., 1999; Matheickal et al., 1999; McKay et al., 1999; Veglio and Beolchini, 1997).

Freundlich expression is an empirical equation based on sorption on a heterogeneous surface (Freundlich, 1906). The empirical Freundlich equation based on sorption on a heterogeneous surface is given below by Eq. 9:

$\log \mathrm{Q}=\log \mathrm{K}_{\mathrm{f}}+1 / \mathrm{n} \log \mathrm{C}_{\mathrm{eq}}$

Where, $\left(\mathrm{K}_{\mathrm{f}}\right)$ and $(\mathrm{n})$ are the Freundlich constants characteristic of the system and are indicators of adsorption capacity and adsorption intensity, respectively. The derivation of the Temkin isotherm (Kolasniski, 2001) assumes that the fall in the heat of sorption is linear rather than logarithmic, as implied in the Freundlich equation.

The Temkin isotherm is generally applied in the following form:

$\mathrm{Q}_{\mathrm{eq}}=\mathrm{a}_{\mathrm{t}}+\mathrm{b}_{\mathrm{t}} \ln \mathrm{C}_{\mathrm{eq}}$

Where, $b_{\mathrm{t}}$ and $a_{\mathrm{t}}$ represent isotherm constants related to the adsorption capacity of the adsorbent. The linearized Langmuir, Freundlich and Temkin adsorption isotherms of $\mathrm{Al}^{3+}, \mathrm{Fe}^{3+}, \mathrm{Zn}^{2+}$ and $\mathrm{Pb}^{2+}$ ions were obtained at the temperature of $25^{\circ} \mathrm{C}$. The three models adsorption constants evaluated from the isotherms with their corresponding correlation coefficients are presented in Table 2. As seen from Table 2, very high regression correlation coefficients $\left(\mathrm{R}^{2}>0.9\right)$ were found for the Langmuir model, whereas high regression correlation coefficient for Freundlich model was found only in case of $\mathrm{Pb}^{2+}$. According to these results, the Langmuir model is more suitable for describing the biosorption equilibrium of $\mathrm{Al}^{3+}, \mathrm{Fe}^{3+}, \mathrm{Zn}^{2+}$ and $\mathrm{Pb}^{2+}$ by Typha biomass in the studied concentration range. An adsorption isotherm is characterized by certain constants; the values of which express the surface properties and affinity of the sorbent and can also be used to find the biosorptive capacity of biomass. The values of $\mathrm{R}^{2}$ are regarded as a measure of the goodness-of-fit of experimental data on the isotherm models (El-Ashtoukhy et al., 2008). The applicability of the three isotherm models for the present data follows approximately the order: Langmuir > Freundlich > Temkin, for all the studied metal ions. The essential characteristic of the Langmuir isotherm may be expressed in terms of dimensionless separation parameter $R_{\mathrm{L}}$, which is indicative of the isotherm shape that predicts whether 
Int. J. Environ. Sci. Tech., 6 (2), 243-248, Spring 2009

Table 1: The first-order and the second-order sorption rate constants for $\mathrm{Al}^{3+}, \mathrm{Fe}^{3+}, \mathrm{Zn}^{2+}$ and $\mathrm{Pb}^{2+}$

\begin{tabular}{lccccrrr}
\hline & \multicolumn{3}{c}{ Pseudo first order } & \multicolumn{3}{c}{ Pseudo second order } \\
\cline { 2 - 7 } & $K_{1, \text { ad }} / \mathrm{min}$ & $\begin{array}{c}\mathrm{Q}_{\text {eq. }} \\
(\mathrm{mg} / \mathrm{g})\end{array}$ & $\mathrm{R}^{2}$ & $\begin{array}{c}K_{2, \text { ad }} \\
\mathrm{g} / \mathrm{mg} / \mathrm{min}\end{array}$ & $\begin{array}{c}\mathrm{Q}_{\text {eq. }} \\
(\mathrm{mg} / \mathrm{g})\end{array}$ & $\mathrm{R}^{2}$ & $\begin{array}{r}\mathrm{Q}_{\text {eq }} \text { experimental } \\
(\mathrm{mg} / \mathrm{g})\end{array}$ \\
$\mathrm{Al}^{3+}$ & 0.0048 & 0.98 & 0.918 & 0.0622 & 0.677 & 0.67875 \\
$\mathrm{Fe}^{3+}$ & 0.0098 & 1.04 & 0.8932 & 0.0465 & 0.99 & 0.8948 & 1 \\
$\mathrm{Zn}^{2+}$ & 0.0199 & 0.76 & 0.8667 & 0.0413 & 0.29 & 0.9291 \\
$\mathrm{~Pb}^{2+}$ & 0.037 & 0.40 & 0.7005 & 0.267 & 0.132 & 0.9825 & 0.1167 \\
\hline
\end{tabular}

Temp.: $25^{\circ} \mathrm{C}$; agitation rate: $100 \mathrm{rpm}$; biomass concentration: $0.5 \mathrm{~g} / 50 \mathrm{~mL}$; $\mathrm{pH}$ : 2.5 ; initial ions concentrations: $\mathrm{Al}^{3+}(7 \mathrm{mg} / \mathrm{L}), \mathrm{Fe}^{3+}(10 \mathrm{mg} / \mathrm{L}), \mathrm{Zn}^{2+}$ (4 mg/L) and $\mathrm{Pb}^{2+}(1 \mathrm{mg} / \mathrm{L})$

Table 2: Sorption isotherm coefficients of Langmuir, Freundlich and Temkin models applied to $\mathrm{Al}^{3+}, \mathrm{Fe}^{3+}, \mathrm{Zn}^{2+}$ and $\mathrm{Pb}^{2+}$ biosorption by Typha biomass

\begin{tabular}{|c|c|c|c|c|c|c|c|c|c|}
\hline \multicolumn{4}{|c|}{ Langmuir } & \multicolumn{3}{|c|}{ Freundlich } & \multicolumn{3}{|c|}{ Temkin } \\
\hline & $\mathrm{Q}_{\max }(\mathrm{mg} / \mathrm{g})$ & $\mathrm{b}(\mathrm{L} / \mathrm{mg})$ & $\mathrm{R}^{2}$ & $\mathrm{~K}_{\mathrm{f}}$ & $\mathrm{n}$ & $\mathrm{R}^{2}$ & $\overline{a_{t}}$ & $\mathrm{~b}_{\mathrm{t}}$ & $\mathrm{R}^{2}$ \\
\hline $\mathrm{Al}^{3+}$ & 0.34825 & 0.287691 & 0.9654 & 0.1538 & 3.82995 & 0.5053 & 1.0012 & 0.815 & 0.4584 \\
\hline $\mathrm{Fe}^{3+}$ & 2.111932 & 2.107927 & 0.9778 & 1.073 & 5.77034 & 0.8883 & 2.3964 & 11.091 & 0.8296 \\
\hline $\mathrm{Zn}^{2+}$ & 0.201349 & 5.412609 & 0.9443 & 0.05516 & 2.282584 & 0.8091 & 0.654 & 0.0523 & 0.8028 \\
\hline $\mathrm{Pb}^{2+}$ & 0.654579 & 1.200842 & 0.9951 & 0.32047 & 3.522367 & 0.9437 & 4,0349 & 0.8814 & 0.8608 \\
\hline
\end{tabular}

Temp.: $25^{\circ} \mathrm{C}$; agitation rate: $100 \mathrm{rpm}$; biomass concentration: $0.5 \mathrm{~g} / 50 \mathrm{~mL}$; $\mathrm{pH}: 2.5$

Table 3: Different values of $R_{\mathrm{L}}$ for the different concentrations of $\mathrm{Al}^{3+}, \mathrm{Fe}^{3+}, \mathrm{Zn}^{2+}$ and $\mathrm{Pb}^{2+}$

\begin{tabular}{|c|c|c|c|c|c|c|c|}
\hline $\begin{array}{c}\mathrm{Al}^{3+} \\
\text { concentration } \\
(\mathrm{mg} / \mathrm{L})\end{array}$ & $\mathrm{R}_{\mathrm{L}}$ & $\begin{array}{c}\mathrm{Fe}^{3+} \\
\text { concentration } \\
(\mathrm{mg} / \mathrm{L})\end{array}$ & $\mathrm{R}_{\mathrm{L}}$ & $\begin{array}{c}\mathrm{Zn}^{2+} \\
\text { concentration } \\
(\mathrm{mg} / \mathrm{L})\end{array}$ & $\mathrm{R}_{\mathrm{L}}$ & $\begin{array}{c}\mathrm{Pb}^{2+} \\
\text { concentration } \\
(\mathrm{mg} / \mathrm{L})\end{array}$ & $\mathrm{R}_{\mathrm{L}}$ \\
\hline 7 & 0.331 & 10 & 0.045 & 4 & 0.044 & 1 & 0.454 \\
\hline 28 & 0.110 & 40 & 0.011 & 16 & 0.011 & 15 & 0.052 \\
\hline 49 & 0.066 & 50 & 0.009 & 24 & 0.007 & 25 & 0.032 \\
\hline 56 & 0.058 & 60 & 0.007 & 32 & 0.005 & 30 & 0.027 \\
\hline
\end{tabular}

an adsorption system is favourable or unfavourable. $R_{\mathrm{L}}$ is defined as (Webi and Chakravort, 1974):

$\mathrm{R}_{\mathrm{L}}=1 /\left(1+\mathrm{b} \mathrm{C}_{0}\right)$

Where, $\mathrm{b}$ is the Langmuir constant. Values of $\mathrm{R}_{\mathrm{L}}$ for $\mathrm{Al}^{3+}, \mathrm{Fe}^{3+}, \mathrm{Zn}^{2+}$ and $\mathrm{Pb}^{2+}$ are given in Table 3. The adsorption process as a function of $\mathrm{R}_{\mathrm{L}}$ may be described as (Chakravarty et al., 2009): Unfavorable when $\mathrm{R}_{\mathrm{L}}>1$; Linear when $\mathrm{R}_{\mathrm{L}}=1$; Favorable when $0<\mathrm{R}_{\mathrm{L}}<1$; Irreversible when $R_{L}=0$. In all cases, the $R_{L}$ values for the present experimental data fall between zero and one, which is an indication of the favourable adsorption of the studied metal ions on the biosorbent (El-Ashtoukhy et al., 2008).

\section{CONCLUSION}

Typha domingensis leaf powder can be used to simultaneously remove aluminium, iron, zinc and lead ions from aqueous solutions. It was noted that the removal process increases with contact time and attains saturation in about $120 \mathrm{~min}$. Metal/biomass isotherms were developed and analyzed according to three isotherm equations. The experimental results were analyzed using the Langmuir, Freundlich and Temkin equations and the data were found to fit the examined models in the order: Langmuir $>$ Freundlich $>$ Temkin, for all the studied metal ions. Adsorption kinetics follows pseudo-second order kinetic model. FTIR investigation of the biomass before and after adsorption showed many changes and shifts in some peaks indicating that there is a metal binding process taking place on the surface of Typha biomass. Typha domingensis biomass was successfully used for $\mathrm{Al}^{3+}, \mathrm{Fe}^{3+}, \mathrm{Zn}^{2+}$ and $\mathrm{Pb}^{2+}$ removal from simulated wastewater. More parameters could also be examined to assess the possibility of the use of biomass for technological applications.

\section{REFERENCES}

Abdel-Ghani N. T.; El-Chaghaby, G. A., (2007). Influence of operating conditions on the removal of $\mathrm{Cu}, \mathrm{Zn}, \mathrm{Cd}$ and $\mathrm{Pb}$ ions from wastewater by adsorption. Int. J. Environ. Sci. Tech., 4 (4), 451-456 (6 pages).

Abdel-Ghani, N. T.; El-Chaghaby, G. A., (2008). The use low cost, environmental friendly materials for the removal of heavy metals from aqueous solutions. Curr. World Environ., 3 (1), 31-38 (8 pages).

Abdel-Ghani, N. T.; Hefny, M.; El-Chaghaby, G. A. F., (2007). Removal of lead from aqueous solution using low-cost abundantly available adsorbents. Int. J. Environ. Sci. Tech., 4 (1), 67-73 (7 pages). 
Abdel-Ghani, N. T.; Hefny, M.; El-Chaghaby, G. A., (2008). Removal of metal ions from synthetic wastewater by adsorption onto Eucalyptus camaldulenis tree leaves. J. Chilean Chem. Soc., 53 (3), 1585-1587 (3 pages).

Al-Anber, Z. A.; Matouq, M. A. D., (2008). Batch adsorption of cadmium ions from aqueous solution by means of olive cake. J. Hazard. Mater., 151 (1), 194-201 (8 pages).

Bayat, B., (2002). Combined removal of zinc (II) and cadmium (II) from aqueous solutions by adsorption onto high-calcium Turkish fly ash. Water Air Soil Poll. 136 (1-4), 69-92 (24 pages).

Chakravarty, S.; Pimple, S.; Hema, S.; Chaturvedi, T.; Singh, S.; Gupta, K. K., (2009). Removal of copper from aqueous solution using newspaper pulp as an adsorbent. J. Hazard. Mater., 159 (2-3), 396-403 (8 pages).

Chandra S., K.; Kamala, C. T.; Chary, N. S.; Anjaneyulu, Y., (2003). Removal of heavy metals using a plant biomass with reference to environmental control. Int. J. Miner. Proc., 68 (1-2), 37-45 (9 pages).

Donmez, G. C.; Aksu, Z.; Ozturk, A.; Kutsal, T., (1999). A comparative study on heavy metal biosorption characteristics of some algae. Proc. Bioch., 34 (9), 885-892 (8 pages).

Ekmekyapar, F.; Aslan, A.; Kemal Bayhan, Y.; Cakici A., (2006). Biosorption of copper (II) by nonliving lichen biomass of Cladonia rangiformis hoffm. J. Hazard. Mater., B137, 293298 (6 pages).

El-Ashtoukhy, E. S. Z.; Amin, N. K.; Abdelwahab, O., (2008). Removal of lead (II) and copper (II) from aqueous solutionusing pomegranate peel as a new adsorbent. Desalination, 223 (1-3), 162-173 (12 pages).

Freundlich, H. M. F., (1906). Uber die adsorption in lösungen. Zeitschrift für Physikalische Chemie. 57, 385-470 (85 pages).

Huamán Pino, G., Souza de Mesquita, L. M., Torem M. L.; Saavedra Pinto, G. A., (2006). Biosorption of cadmium by green coconut shell powder. Mine. Eng., 19 (5), 380-387 (8 pages).

Gupta, G.; Torres, N., (1998). Use of fly ash in reducing toxicity of and heavy metals in wastewater effluent. J. Hazard. Mater. 57 (1), 243-248 (6 pages).

Ho, Y. S.; McKay, G., (1999). Pseudo-second order model for sorption processes. Proc. Biochem., 34(5):451-465 (5 pages).

Horsfall, M. Jr.; Abia, A. A., (2003). Sorption of Cd(II) and $\mathrm{Zn}$ (II) ions from aqueous solutions by cassava waste biomass (Manihot sculenta Cranz). Water Res., 37 (20), 4913-4923 (11 pages)

Horsfall, M. J.; Ogban, F. E.; Akporhonor, E. E., (2006). Recovery of lead and cadmium ions from metal-loaded biomass of wild cocoyam (Caladium bicolor) using acidic, basic and neutral eluent solutions. Electron. J. Biotech., 9 (2), 152156 (5 pages).

Ilharco, L. M.; Garcia, A. R.; Lopes da Silva, J.; Vieira Ferreira, L. F., (1997). Infrared approach to the study of adsorption on cellulose: Influence of cellulose crystallinity on the adsorption of benzophenone. Langmuir, 13 (15), 4126-4132 (7 pages).

Kolasniski, K. W., (2001). Surface Science. Wiley, Chister, UK.

Lagergren S., (1898). Zur theorie der sogenannten adsorption gelöster stoffe. Kungliga Svenska Vetenskapsakademiens. Handlingar, 24 (4), 1-39 (39 pages).

Langmuir, I., (1918). The adsorption of gases on plane surfaces of glass, mica and platinum. J. Am. Chem. Soc., 40 (9), 13611368 (8 pages).

Manal, F., (2007). Biosorption of cadmium and lead by phragmites Australis L. biomass using factorial experiment design. Global J. Biotech. Biochem., 2 (1), 10-20 (11 pages).

Matheickal, J. T.; Yu, Q.; Yin, P.; Kaewsarn, P., (1999). Heavy metal uptake capacities of common marine macro algal biomass. Water Res., 33 (6),1534-1537 (4 pages).

McKay, G.; Ho, Y. S.; Ng, J. C. Y., (1999). Biosorption of copper from wastewaters: A review. Separ. Purif. Method., 28 (1), 87-125 (39 pages).

Pandey, P. K.; Verma, Y.; Choubey, Sh., Pandey, M.; Chandrasekhar, K., (2008). Biosorptive removal of cadmium from contaminated groundwater and industrial effluents. Bioresour. Tech., 99 (10), 4420-4427 (8 pages).

Selatnia, A.; Boukazoula, A.; Kechid, N.; Bakhti, M. Z.; Chergui, A., (2004). Biosorption of $\mathrm{Fe}^{3+}$ from aqueous solution by a bacterial dead Streptomyces rimosus biomass. Proc. Biochem., 39 (11), 1643-1651 (9 pages).

Singh, K. K.; Rastogi, R.; Hasan, S. H., (2005). Removal of cadmium from wastewater using agricultural waste rice polish. J. Hazard. Mater., 121 (1-3), 51-58 (8 pages).

Veglio, F.; Beolchini, F., (1997). Removal of metals by biosorption: A review. Hydrometallurgy, 44 (3), 301-316 (16 pages).

Webi T. W.; Chakravort, R. K., (1974). Pore and solid diffusion models for fixed bed adsorbents. J. Am. Inst. Chem. Eng., 20 (2), 228-238 (11 pages).

Zafar, M. N.; Nadeem, R.; Hanif, M. A., (2007). Biosorption of nickel from protonated rice bran. J. Hazard. Mater., 143 (12), 478-485 (8 pages).

\section{AUTHOR (S) BIOSKETCHES}

Abdel Ghani, N. T., Professor of analytical and inorganic chemistry in the Chemistry Department, Faculty of Science, Cairo University, Egypt. Email: noureta2002@yahoo.com

Hegazy, A. K., Professor of Conservation and Applied Ecology in the Botany Department, Faculty of Science, Cairo University, Egypt. Email: akhegazy@yahoo.com

El-Chaghaby, G. A., M.Sc., Assistant researcher in Agriculture Research Center, Egypt; Ph.D. student in Chemistry Department, Faculty of Science, Cairo University, Egypt. Email: ghadiraly@yahoo.com 